\title{
Shamans and Sacred Landscapes in Buriatiia
}

\author{
KATHERINE METZO
}

$\mathrm{T}$ he three articles in this issue of Sibirica focus on the ways in which sacred landscapes have been (re)integrated into the ritual life of indigenous Buriats, as well as how they can become contested terrains. Once considered the opiate of the masses by Soviet leaders, religion is no longer "dangerous" in Russia. Decades of institutionalized atheism have taken their toll, however, as sacred sites have been secularized, shamans have lost links to their ongons, and Buriats have forgotten their clan affiliations. In the past decade and a half, shamanism has reemerged and practitioners are striving to revive and re-invent the practice to return shamanism to a central position in the everyday lives of rural and urban communities.

Buriatiia has been central to discussions of shamanism in the postSoviet period. In the three articles collected here, the authors tackle the theme of sacred landscape and shamanism in a variety of ways. Buck Quijada focuses on a ritual at a site made sacred for the purposes of reconnecting Buriats with the spirits, namely their clan ancestors. Jokic takes up more explicitly what Buck Quijada leaves implicit-a shaman's sacred landscape is not limited to the earthly realm. Rather, shamans move between worlds, appealing to and calling down spirits from their positions in the upper and lower worlds. Communication with the spirit world is achieved (or at the very least attempted) through trance. Metzo deals with a place in the sacred landscape in which shamans play virtually no contemporary role. ${ }^{1}$ Nevertheless, local residents and Buddhist competitors continue the practice of shamanic offerings to the master spirits (ezhin). Each of the papers deals with various disjunctures produced by the transition from state socialism to capitalism, situating shamans and/or their clients within a sacred landscape.

Two of the articles in this issue (Buck Quijada and Metzo) were originally presented at the American Anthropological Association meet- 
ings in 2006 on a panel devoted to the topic "Shamanic Landscapes in Inner Asia." Using the term "shamanic landscape" was not an intentional invocation of Humphrey's use of the term to describe "the ability to manifest in inspirational performances the energies perceived in 'nature'" (1995: 138). Rather, the authors set out to demonstrate the dynamism, flexibility, and heterogeneity of contemporary shamanic practice as well as how pre-Soviet shamanisms have infused deep cultural meanings about the landscape into the minds of local indigenous and non-indigenous residents throughout Siberia and Mongolia. Humphrey's articulation of the difference between chiefly and shamanic landscape, however, can be mapped onto some aspects of the three articles in this issue. A key difference between chiefly and shamanic rituals is the aim of the rituals in relation to the spirits. Chiefly rituals focus on "beckoning" spirits through prayers and offerings, while shamanic rituals focus on the use of trance (Humphrey 1995: 139). Metzo's article emphasizes the former, while Jokic's article emphasizes the latter. Buck Quijada's article highlights the tensions inherent in such neat divisions when applied in a post-Soviet setting. Humphrey (1998) herself notes that the presence of a shaman has not always been a requirement for conducting tailgan. Buck Quijada shows us that chiefly ritual, so dependent upon clan affiliation, can be re-formulated with the help of a shaman's trance ability combined with the certainty that "the ongons will know" your clan. Metzo's article shows how the chiefly and shamanic landscapes are overlaid with Buddhist and commercial landscapes.

In the summer of 2005 both Jokic and Buck Quijada worked in Ulan-Ude with the same shaman's association, Tengeri, but here each emphasizes different aspects of the Tengeri shamans' relations to urban and rural landscapes. In "Shamans in the City," Humphrey (1999) illustrates how the shamans situate themselves in the new terrain of post-Soviet urban life and suggests that atheist indoctrination and education of those who came of age within the Soviet Union and later became shamans has led to a crisis of practice. Similarly, Balzer (1999) talks of the ambivalence Khanty felt toward shamans, noting the success of the Soviet anti-religious campaigns in shifting attitudes about shamanism. Humphrey illustrates how shamans, through narrative and practice, "re-territorialize" urban subjects. Both Buck Quijada and Jokic mention Tengeri's offices in the center of Ulan-Ude, which provide a space for the sacred within the heart of the city. The city tailgan at the Hippodrome (as well as the one at the Ethnographic Museum [see Metzo in press]) creates not only a ritual community, but quite lit- 
erally, creates a (temporary) sacred site. In this space, ongons from all over Buriatiia are called in the service of their clansmen.

Buyandelgerin discusses a very different kind of crisis, one involving the spirits themselves. Uheer are new spirits, souls of those who were victims of Stalin's Great Terror (Buyandelgerin 2006). These souls can block the paths of their descendants, causing illness and suffering. While these specific spirits have not been discussed by those studying ethnic Buriats who live in Russia, Buck Quijada notes that all kinds of ancestor spirits make knowing one's clan imperative for effective treatments. In a similar vein, Jokic examines a break with the past, but suggests that it is not a break with the practice and beliefs of shamanism per se, rather it is a break with one's ongons. Without the connection to one's ongons, a shaman is unable to progress to higher levels of shamanic initiation. Further, without initiation one's ability to master the complexities of communicating with the spirit world is significantly reduced. Living away from the territory of one's ongons and finding a way to make room for new spaces and new spirits in the post-Soviet era is a challenge for shamans who are trying to demonstrate their "authenticity."

Elsewhere I have tried to make sense out of the trends that these, and other, authors have noted. I have argued that Buriat shamans in particular, and perhaps Siberian shamans more broadly, are "mediators of multiple worlds" (Metzo in press). It has been frequently asserted that shamanism is a malleable or adaptive practice and I have suggested that contemporary Buriat shamans have expanded the "traditional" role of shamans as mediators between the earthly world and the spirit world. Today, shamans continue to mediate between spirits, ancestors, and living Buriats, but have begun mediating the worlds of the media, allopathic medical care, and the state as well. This greatly expanded set of responsibilities derives in part from the need to demonstrate the authenticity of contemporary shamanic practice in the face of successful atheist propaganda. They want to educate their varied audiences while finding a place for shamanism within the increasingly regulated terrain of "original" religions of Russia (Metzo in press). At the same time, shamans combat the Soviet propaganda by using tools acquired during their years in the Soviet education system and employment in the cultural sector, making their contemporary existence both a response to state atheism and a product of state modernization campaigns (Metzo in press). Jokic and Buck Quijada join other scholars in noting these characteristics of what is commonly referred to as neoshamanism (Balzer 1999; Buyandelgerin 1999; Humphrey 1999; Metzo 
in press; Zhukovskaia 2000, 2004). Buck Quijada makes an important point regarding shamans' rejection of the term neo-shamanism, noting that they see their work as rebuilding a "traditional" Buriat shamanism. Part of this rebuilding, I would argue, is finding a way within the contemporary political climate to preserve the sacred landscape. In the case of shamanic associations, this means an emphasis on those sites of republic-wide significance, such as Bukha-Noion (described in Metzo in press).

Finally, I would like to come back to the landscape itself. Balzhan Zhimbiev (2001) has written about the urbanization of Ulan-Ude, noting that the city was not built on top of empty space. Describing the nomadic patterns of Buriats, he illustrates how the use of the natural landscape also creates a cultural landscape, even when that landscape appears "untouched" by outsiders. The cultural landscape is represented by an oboo (the trees or posts covered in ribbons), which instantly indicates the existence of a sacred site to passerbys. While on the steppe, a sacred site is instantly visible to visitors, in the contemporary landscape of Ulan-Ude there is little that makes shamanic spaces stand out. The offices of Tengeri are hardly distinguishable from the surrounding offices and buildings. ${ }^{2}$ Even more striking is the ease and speed with which the Hippodrome (or Ethnographic Museum) is transformed from a secular, urban, athletic space to a sacred stage and back to a mundane, secular space. Passing these urban spaces several days after the completion of a ritual, there is no indication that the space had served, at least for the period of a day, as a sacred site. At the same time, sacred spaces "in nature" are being transformed into tourist spaces (see also Bernstein 2006). Metzo's (in press) case in Arshan shows how institutional space, the sanatorium, and sacred space are converging.

Each of the three articles included in this issue is, in many ways, a snapshot. Thus, each situation described is an image of what is happening in Buriatiia now. The authors talk about processes-processes of degradation, both of knowledge and the landscape itself; processes of learning, renewal, and reinvention-which suggest that the moments we observed will soon be transformed. By looking at shamanism through the lens of landscape, we provide a different lens through which to view social and religious transformations in the post-Soviet space. Using the idiom of landscape allows the authors to focus on these transitional moments and to think about movement. While we may talk about the aims of actors (shamans, laypersons, Buddhist lamas), we do not suggest that movement is unidirectional or certain. By talking about the place of shamans and spirits in these sacred land- 
scapes, we also begin to expand the discussion of landscape. The focus on sacred landscape shows that in addition to being geographic and natural, sacred landscape is also cultural, temporal, and otherworldly.

\section{Notes}

1. This is not to suggest that they do not play a role in village life or at other sacred sites in the area.

2. This may change, however, as Tengeri fulfills its plans for the construction of a shamanic center (see also Balzer 2005).

\section{References}

Balzer, Marjorie Mandelstam. 1999. The Tenacity of Ethnicity: A Siberian Saga in Global Perspective. Princeton, NJ: Princeton University Press.

—. 2005. "Whose Steeple Is Higher? Religious Competition in Siberia." Religion, State and Society 33 (1): 57-69.

Bernstein, Anya. 2006. In Search of the Siberian Shaman. Film distributed by Documentary Educational Resources.

Buyandelgerin, Manduhai. 1999. "Who 'Makes' the Shaman?: The Politics of Shamanic Practices among the Buriats in Mongolia" Inner Asia 1: 221-244.

—. 2006. "Raised Corpses: Transformation in the Constituency of the Shamanic Spirit." Paper presented at the American Anthropological Association meetings in San Jose, California, 15 November 2006.

— N.d. "Tragic Spirits: Shamanism and the State of Post-Socialism in Mongolia." Unpublished manuscript.

Humphrey, Caroline. 1995. "Chiefly and Shamanist Landscapes in Mongolia." Pp 135-162 in The Anthropology of Landscape: Perspectives on Place and Space, ed. Eric Hirsch and Michael O'Hanlon. Oxford: Oxford University Press.

_. 1998. Marx Went Away_But Karl Stayed Behind. Ann Arbor: University of Michigan Press.

—. 1999. "Shamans in the City." Anthropology Today. 15 (3): 3-10.

Metzo, Katherine. in press. "Shamanic Transformations: Buriat Shamans as Mediators of Multiple Worlds." In Reclaiming the Sacred: Morality, Community, and Religion after Communism, ed. Mark Steinberg and Cathy Wanner. Washington, DC: Woodrow Wilson Foundation Press.

Zhimbiev, Balzhan. 2001. History of the Urbanization of a Siberian City: Ulan Ude. Cambridge, UK: White Horse Press.

Zhukovskaia, Natalia L. 2000. "Neo-Shamanism in the Context of the Contemporary Ethno-Cultural Situation in the Republic of Buryatia." Inner Asia 2(1): 25-36.

2004. "Neoshamanizm v Buriatii." Pp. 390-396 in Buriaty, ed. Abaeva and Zhukovskaia. Moskva: Nauka. 